\title{
The Kovel Doctrine: Issues And The Perils Of Discovery
}

Mark A. Segal, University of South Alabama, USA

\begin{abstract}
To what extent are accountant work product and communications subject to discovery? Defining the parameters of this decision has significant stakes for both accountants and their clientele. This article seeks to examine an aspect of this issue by focusing on certain issues and cases concerning what has come to be known as the Kovel doctrine. Where this doctrine is applicable it can help protect certain communications and work product from disclosure. Where assertion of the doctrine fails there is an increased vulnerability to discovery, further litigation and risk to finances and reputation.
\end{abstract}

Keywords: Kovel Doctrine; Work Product; Waiver; IRS; AICPA Rule 301; Hatfield; Comcast

\section{INTRODUCTION}

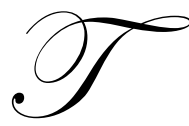

he extent to which communication between a professional and clientele is vulnerable to discovery by third parties has significant implications with respect to the candor and openness of the professionalclient relationship. Over time judicial doctrines and statutes have been established which may provide possible protection from discovery. Examples of these include: the work product doctrine, attorney-client privilege, and tax practitioner privilege (I.R.C. Section 7525). While Section 7525 may be availed of by accountants in certain instances, the work product doctrine and attorney-client privilege are more targeted to attorneys, and may be applicable to accountants derivatively. In this regard what has come to be known as the Kovel doctrine has frequently been asserted as grounds for nondisclosure in certain cases involving accountants. This paper seeks to examine certain aspects of this doctrine and its application.

The accounting profession's general approach with respect to client confidentiality, and susceptibility to discovery, is reflected in Rule No. 301 of the AICPA Code of Professional Responsibility. According to this provision:

" A CPA in the practice of public accounting must not disclose confidential client data without the specific consent of the client. However, Rule 301 does not, apply in the following situations:

1) If there is a conflict with Rule 202 (Compliance with Standards) and 203 (Accounting Principles) as set forth by the AICPA Code of Professional Conduct.

2) If the CPA is served with an enforceable subpoena or summons, or must comply with applicable laws and government regulations;

3) If there is a review of a CPA's practice under AICPA or state society authorization; or

4) If the CPA is responding to an inquiry of an investigative or disciplinary body of a recognized society, or where the CPA is initiating a complaint with a disciplinary body."

"In connection with this rule members of the investigative bodies who may be exposed to confidential client information are precluded from disclosing such information."

\section{Kovel Doctrine}

The Kovel Doctrine constitutes another grounds upon which to protect certain communications between an attorney and accountant from discovery. In actuality the Kovel Doctrine is an extension of attorney -client 
privilege. The Doctrine originated in the 1961 Kovel case. The doctrine provides that an attorney can consult with a nonlawyer, e.g., an accountant, with such communication being privileged, should the communication be needed to assist in the rendering of legal services. According to the Second Circuit in order for protection to attach under Kovel it must be found that "... the accountant is necessary, or at least highly useful, for the effective consultation between the client and the lawyer which the privilege is designed to permit." The mere facilitation of accounting services by the accountant is not protected by the Kovel. Furthermore, should the parties have a prior business relationship which lacks protection from discovery, such as consultant and client, the provision of similar type services might arguably be viewed as an extension of such type services (See in this regard In re G-I Holdings Inc.). In contrast, having a formal agreement between the attorney and accountant which documents that the accountant is retained by the attorney (not the client entity) and that the type of service that is to be rendered (or item to be reviewed) by the accountant pertain primarily to the rendering of legal services advances the argument that the accountant is primarily involved in the rendering of a legal service.

\section{The Kovel Letter}

In seeking Kovel protection the accountant should be engaged to work by and under the auspices of an attorney pursuant to what has been referred to as a Kovel letter. Often the expression "necessary" should be used in the engagement letter in connection with the need for retention of the accountant. Although it may be arguable, the expression reflects the significance of the accountant to the rendering of the legal services. In adopting this position one should be prepared to defend it based upon the purported complexity of the transaction, e.g., the financial and accounting issues involved, the need for understanding and analysis related to internal control, accounting rules, regulations and concepts, and principles, and financial statements, as such relate to legal services. See in this regard the case of Comcast wherein the Court took a rigid approach to attorney-client privilege and held that the information involved was protected from discovery largely based upon the work product doctrine.

\section{A New Concern}

For many years utilization of the Kovel doctrine has been recognized and served as a basis for protecting communication between an attorney and accountant from discovery. More recently concern has arisen that the doctrine may be subjected to more vigorous attack by the Internal Revenue Service. According to one commentator the Internal Revenue Service has indicated it will more vigorously challenge application of the Kovel doctrine. This position is supported by a 2010 statement attributed to Janet Johnson, Deputy Chief Division Counsel for Criminal Tax, who was reported to have said "We will take the position that the accountant is independently working and not covered by privilege." (See Karter).

The following sections of this paper further examine the parameters of the Kovel doctrine and certain recent cases concerning it.

\section{Comcast Corp.: A Backdrop}

A case drawing attention concerning the Kovel doctrine, and the possibility of waiver, is that of Commissioner of Revenue v. Comcast Corp., 453 Mass. 293 (2009). A major issue in the case concerned whether an attorney had waived a legal protection by consultation with an outside accounting firm (Arthur Andersen) concerning assessment of the risk of audit and litigation associated with different options. In addition the attorney (an experienced tax attorney) was unfamiliar with relevant state law and as a result consulted with Arthur Andersen concerning such.

The Service contended that:

1) The consultation with Arthur Andersen resulted in a waiver of attorney-client privilege; and

2) The Commissioner argued that Comcast had the burden of proof to show that attorney-client privilege was applicable and that it had not met such burden due to:

a) A lack of proof that memorandum prepared by Arthur Andersen contained confidential communications from the bottom line client (US West) 
b) The memorandum prepared not qualifying for Kovel treatment (derivative privilege)

c) It would be an improper expansion of privilege to allow Comcast to resist "a statutory demand of information."

The Court ruled that the memorandum by Arthur Andersen was protected by the work product doctrine.

The Court indicated that this decision was based on the memorandum being prepared due to the prospect of litigation. As a result the Court found that such communication was protected by the work product doctrine (despite not being shielded from disclosure by the attorney -client privilege).

\section{Cavallaro}

In Cavallaro v. United States, 284 F.3d 236 ( $1^{\text {st }}$ Cir. 2002), the information produced by the accountant was already possessed by the in-house attorney. Thus, the information sought enhanced but was not critical to the in house attorney's ability to explain the matter to his clientele.

The material prepared by the accountant however was protected on other grounds. For example, the memo would not have been prepared but for the possibility of litigation. The court was in a jurisdiction which used the because of test. The Service was not harmed as in the eyes of the Court the IRS could get comparable information from other sources.

\section{United States v. Hatfield}

The case of United States v. Hatfield provides insight into several issues relevant to legal protection from discovery. The following is a summary of some of the issues raised in the case and their treatment.

1) Kovel relationship - In order to find whether a valid Kovel arrangement existed the Second Circuit distinguished between:

a) The hiring of accountants to aid attorneys in understanding certain matters relevant to carrying out their attorney duties; and

b) The hiring of accountants to render accounting services.

Where the accountant helps the attorney's understanding such that the attorney can better provide legal services the accountant is assisting the client attain legal services. If instead the accountant is providing an accounting service and/or helping the attorney understand an accounting service, then the accountant will likely be perceived to have provided an accounting service, such that attorney-client privilege will not attach.

2) Under the circumstances the court rejected the claim that the work product doctrine shielded the work papers from discovery. The discovery of work papers has been a vital battleground in several high stakes discovery actions. Citing Adlman the Second Circuit noted the distinction between:

a) "Documents created "because of" litigation, and

b) Documents prepared in the ordinary course of the business or that would have been created in essentially similar form irrespective of the litigation."

Note that scant protection apples to documents prepared in the ordinary course of the business.

Thus, if an accountant is an employee of a company it is often difficult to claim that the accountant's work product for that company is shielded from discovery by either the work product doctrine, privilege or Kovel.

3) Arguments that the work product doctrine should attach must also be supported by the use of "reasonable precautions" to avert being considered to have waived such right. Note that the fact that inadvertent disclosure may imperil but not necessarily waive work product protection so long as "reasonable precautions were taken"

4) The Court in Hatfield ruled that based upon the facts, and applying the decision of Medinol, there had been a waiver. In reaching this conclusion the court stated:

a) "The independent auditor assumes a public responsibility transcending any employment relationship with the client." The auditor has a duty to maintain independence and retain fidelity toward the public interest.

b) Potential adversity exists between an auditor and the company attorney due to their different roles. An Attorney is an advocate for the client whereas the public accountant in the role of auditor is the watchdog of the public. 
c) The auditor (Rachlin) as a "pubic watchdog" should have been viewed as adverse to the company in that the auditor had expressed concern over:

1. 'DHB's management; and

2. a responsibility to publicly reveal the truth."

3. "...by asking Huron to cooperate with Rachlin, Mr. Brooks provided Rachlin with some of the very information it used to make finding detrimental to his interests. Sharing potentially inculpatory information with an entity dedicated to uncovering financial irregularities is entirely inconsistent with the zone of privacy that underlie(s) the work product doctrine." As a result the court found the provision of the work papers to the auditor to constitute a waiver.

4. The attorney failed to take reasonable precautions regarding having work product be used nor did the attorney voice an objection to the arrangement - allowing it to happen.

Subsequently the court noted its receipt of summaries of SEC depositions prepared by the attorney the court found such items to be protected by the work product doctrine.

In other respects certain of the protective rights were maintained. For example, a waiver was not found to have been made as a result of the placement of "documents on the hard drive."

5) The Court went on to indicate where there is a lack of raising a defense or asserting rights whether waiver of such rights or privileges has occurred depends on several factors. Included in such factors cited by the court are:

1. "The reasonableness of the precautions taken by the producing party to prevent inadvertent disclosure of privileged documents

2. The volume of discovery versus the extent of the specific disclosure

3. The length of time taken by the producing party to rectify the disclosure

4. The overarching issue of fairness."

\section{CONCLUSION}

The Service and taxpayers have long battled over what is subject to discovery. The Kovel doctrine and its parameters have become an important issue in this struggle. An awareness of the relevant cases, statutes, doctrines and items such as the Kovel doctrine can enhance the ability to structure one's affairs so as to better avert waiver of legal rights and the jeopardizing of one's case.

\section{AUTHOR INFORMATION}

Mark A. Segal, MBA, J.D., LL.M., is a professor of Accounting in the Mitchell College of Business at the University of South Alabama. He has written numerous articles on tax and accounting topics which have appeared in academic and professional journals. E-mail: msegal@usouthal.edu

\section{REFERENCES}

1. $\quad$ Adlman, 68 F.3d 1495 (2d Cir. 1995).

2. $\quad$ United States v. Kovel, 296 F. 918 (2d Cir. 1961).

3. Medinol v. Boston Scientific Corp, 294 FRD 113 (SDNY 2002).

4. $\quad$ United States v. Hatfield, 210 WL 183522 (EDNY 2010).

5. Attorney Client Privilege: CPAs and the E Frontier ; CPAs Performing Litigation Support must be Careful Not to Inadvertently Waive Privielge , Journal of Accountancy (2007), by Pacini, Carl, William Hillison, M.G. Ferema, and Ray Placid.

6. $\quad$ Commissioner v. Comcast, 453 Mass. 293 (March , 2009).

7. Cavallero v. United States, 284 F.3d 236 (2002, USCA $1^{\text {st }}$ Circuit).

8. Squib Note, "Venerable Kovel Rule may be Under Attack," by Phil Karter

9. $\quad$ See In re G-I Holdings, Inc., 218 F.R.D. 428 (D.N.J. 2003). 